\title{
INITIAL DEVELOPMENT AND GAS EXCHANGE OF Talisia subalbens (MART.) RADLK. UNDER DIFFERENT SHADING CONDITIONS ${ }^{1}$
}

\author{
Fernanda Carlota Nery², Hilton Morbeck de Oliveira ${ }^{3}$, Amauri Alves de Alvarenga ${ }^{4}$, Sara Dousseau ${ }^{4}$, \\ Evaristo Mauro de Castro ${ }^{4}$ e Ana Carolina Atala Lombelo Campos ${ }^{4}$
}

\begin{abstract}
Ecophysiological studies under semi-controlled conditions in nurseries and greenhouses are essential to enable the use of native species to recover degraded areas and for commercial planting. Talisia subalbens (Mart) Radlk, 'cascudo', is a native fruiting species of the Cerrado on the verge of extinction. The ecophysiological performance of this species was evaluated in nursery conditions under different levels of shading (full sunshine, 30\%, 50\% and 70\%). Initial growth, biomass allocation, gas exchange and chlorophyll content of the plants were analyzed. Full sunshine cultivated plants showed a higher accumulation of total, shoot, and root dry biomass. There was no significant difference in the root/shoot ratio among the treatments. Seedlings cultivated under full sunshine and 30\% shading showed higher values for height, basal diameter, and leaf area. Differences in stomata conductance and photosynthesis rate were not observed among the different shading levels. Plants cultivated under $70 \%$ of shading had higher contents of chlorophyll $a, b$, and total. During the initial phase with higher levels of radiation were fundamental for the development of $T$. subalbens seedlings.
\end{abstract}

Keywords: Savannah, Growth and Krab.

\section{DESENVOLVIMENTO INICIAL E TROCAS GASOSAS DE CASCUDO (Talisia subalbens (MART.) RADLK.) SOB DIFERENTES CONDIÇÕES DE SOMBREAMENTO}

\begin{abstract}
RESUMO - Estudos de ecofisiologia sob condições semicontroladas em viveiros e casas de vegetação são essenciais para o uso de espécies nativas em programas de recuperação de áreas degradadas e para o plantio comercial. Talisia subalbens (Mart) Radlk, cascudo, é uma espécie frutífera, nativa do Cerrado em vias de extinção. O comportamento ecofisiológico dessa espécie foi avaliado em viveiro sob differentes condições de sombreamento (pleno sol, 30\%, 50\% e 70\%), sendo avaliados o crescimento inicial, a alocação de biomassa, as trocas gasosas e os teores de clorofilas. Plantas sob pleno sol apresentam maior acúmulo de massa seca total, parte aérea e sistema radicular. Para a relação raiz/parte aérea, não houve diferença significativa entre os tratamentos. Mudas cultivadas a pleno sol e a 30\% de sombreamento apresentaram maiores valores de altura, diâmetro do colo e área foliar. Não foram observadas diferenças na condutância estomática e fotossíntese entre os níveis de sombreamento. Os teores de clorofila $a$, b e total foram superiores em plantas a $70 \%$ de sombreamento. Níveis mais elevados de radiação são fundamentais para o desenvolvimento inicial de mudas de T. subalbens.
\end{abstract}

Palavras-chave: Cerrado, Crescimento e Cascudo.

\footnotetext{
${ }^{1}$ Recebido em 16.06.2008 e aceito para publicação em 25.08.2010.

${ }^{2}$ Universidade Federal de São João Del-Rei, UFSJ, Brasil. E-mail: <fernandacarlota@yahoo.com.br>.

${ }^{3}$ Universidade Federal de Mato Grosso, UFMT, Brasil. E-mail: <sahbeck@globo.com>

${ }^{4}$ Universidade Federal de Lavras, UFLA, Brasil.E-mail: >amauriaa@dbi.ufla.br>, <saradousseau@yahoo.com.br>, <emcastro@dbi.ufla.br> e<carolinatala@hotmail.com>.
} 


\section{INTRODUCTION}

Talisia subalbens (Mart.) Radlk (Sapindaceae), commonly known as 'cascudo' and 'cascudinho', is a subshrub species, endemic in Mato Grosso, ranging an area especially restricted to the Cerrado at Chapada of Guimarães. Its fruits are widely appreciated by the local fauna and it has a high potential use in programs to recover degraded and permanent preservation areas (Guarim Neto, 2002).

The use of native species to recover degraded or disturbed areas enhanced substantially during the last years. To evaluate the potential use of these species in programs of reforestation, radiation studies are very important since light availability is a critical factor to their development (Gajego et al., 2001). Plants respond in several ways to light intensity variation. Two essential strategies to face shading conditions are known: (1) modify the development and growth process, avoid shading, (2) or tolerate and maintain the growth pattern (Gajego et al., 2001). The adaptive plasticity of species to different solar radiation conditions depend on their photosynthetic apparatus adjustment. Plants with a higher efficiency in the conversion of radiant energy in chemical energy consequently show higher growth (Alvarenga et al., 2003).

Light has a fundamental importance, both in terms of intensity and quality, since it influences biomass accumulation and distribution, gas exchange, and chlorophyll synthesis, among other characteristics (Almeida et al., 2005a; Lima Junior et al., 2005, 2006; Ramos et al., 2004).

This work aimed to evaluate the initial growth, biomass allocation, gas exchange, and leaf chlorophyll content in young plants of Talisia subalbens under different shading levels.

\section{MATERIALAND METHODS}

Seeds were collected from matrix plants located in the municipality of Chapada dos Guimarães, MT. Seedlings were cultivated in Styrofoam trays (144 cells) in the following substrates: subsoil material, sand, and cattle manure (7:2:1), supplemented with $2 \mathrm{~kg}$ of fertilizer 4:14:8 by $1 \mathrm{~m}^{3}$ of substrate. After that, seedlings were transferred to PVC tubes $(15 \mathrm{~cm}$ x $30 \mathrm{~cm})$ containing the same substrate.

Revista Árvore, Viçosa-MG, v.35, n.1, p.61-67, 2011
Seedlings were kept in a nursery under 30\% shading for five months. After that, they were submitted to three shading levels (30\%, 50\%, and 70\%) using screen mesh and a treatment under full sunshine (0\%), control. During the evaluation period seedlings were monthly fertilized with Johnson et al. (1957) modified nutrient solution.

Gas exchange records were made in simple leaves completely expanded, located in the second node counting from the apex, on clear sunny days. Photosynthetic photon flux density (PPFD) and leaf temperature were evaluated using the infrared gas analyzer of open flux (LCA4, Analytical Development Co., Hoddesdon, UK). Records were measured between 09 and $10 \mathrm{~h}$. Air relative humidity and temperature data in the leaf chamber were used to calculate the vapor pressure deficit (VPD).

Chlorophyll content was determined using three simple leaves completely expanded and located in the middle region of the plants. Evaluation of chlorophylls $a, b$, and total was made according to the methodology of Arnon (1949).

Plant growth was measured based on plant length and basal diameter, shoot and root dry biomass. Leaf area was measured by an integrator of leaf area Model LI-3100 Area Meter trade LICOR.

The experimental design was completely randomized with each treatment composed of 25 plants and each plant was considered a replicate. The data obtained were submitted to the variance analysis and to the average test using the statistical program Sisvar (Ferreira, 2000).

\section{RESULTS AND DISCUSSION}

Records from photosynthetic photon flux density (PPFD) and vapor pressure deficit (VPD) showed alterations in the physical characteristics of the environment considering the shading levels to which $T$. subalbens seedlings were submitted (Figure 1).

The highest values of VPD were observed in April. Plants under shading treatment showed higher values of VPD in August and December of 2004. This fact coincided with the beginning of the year dry season in the region where this study was carried out, which

Revista Arvore, Viçosa-MG, v.35, n.1, p.61-67, 2011 


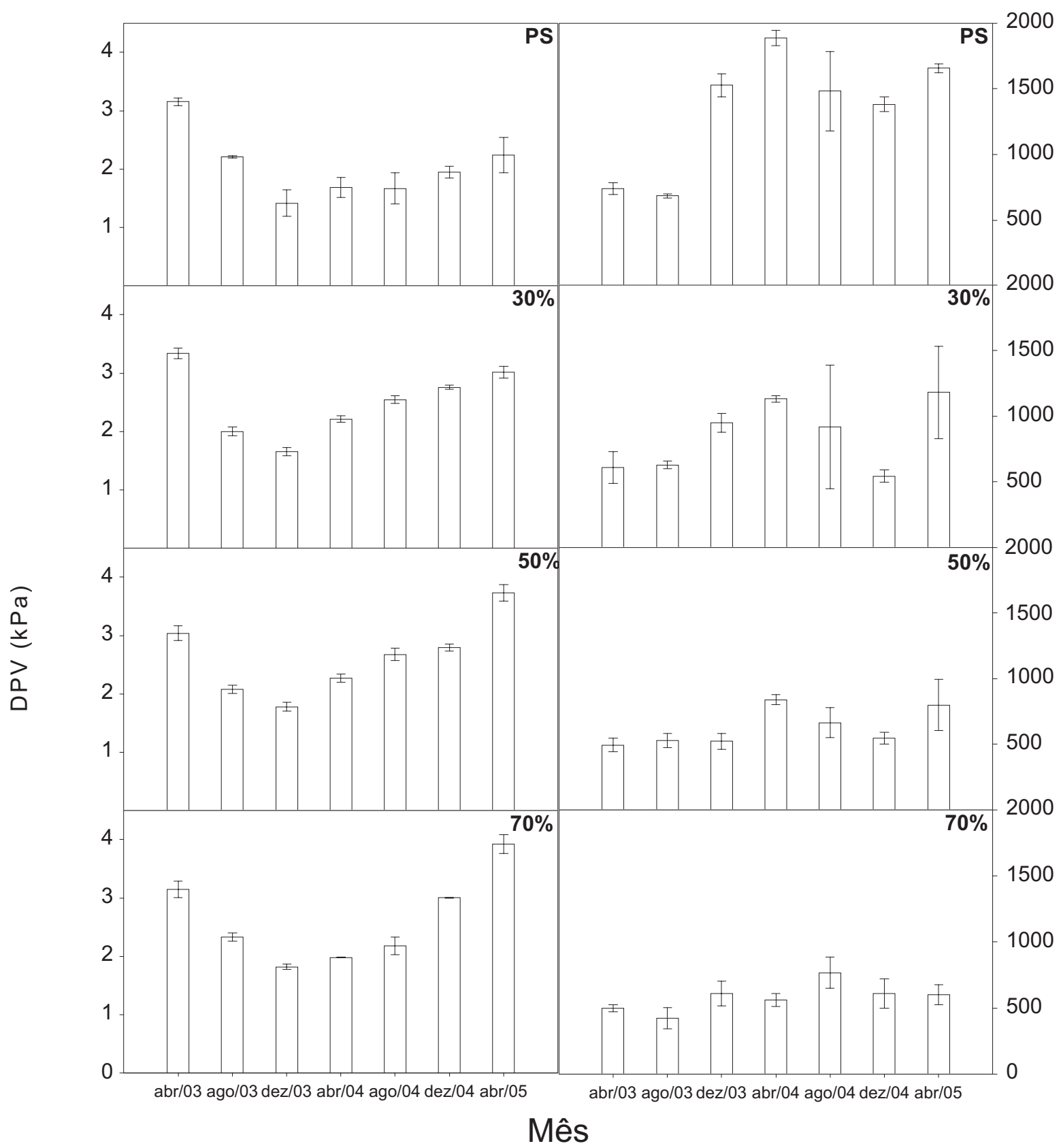

Figure 1 - Average values ( \pm standard error) of photosynthetic photon flux density (PPFD) and vapor pressure deficit (VPD) of T. subalbens plants under different shading levels during eight evaluation dates.

Figura 1 - Valores médios ( \pm erro padrão) da densidade de fluxo de fótons fotossinteticamente ativos (DFFFA) e déficit de pressão de vapor (DPV) em plantas de Talisia subalbens (Mart) Radlk. submetidas a diferentes níveis de sombreamento.

is characterized by low air relative humidity and a decrease in temperature. Data from PPFD showed that plants submitted to full sunshine conditions received higher radiation intensity than the three shading levels in
April and August 2003. It was observed that PPDF tended to increase in treatments with $50 \%$ shading in April 2004 and 2005 and with 70\% shading in August 2004 (Figure 1).

Revista Árvore, Viçosa-MG, v.35, n.1, p.61-67, 2011 
Stomatal conductance and transpiration showed divergent responses (Figure 2). In December 2003, when a higher precipitation and PPDF was expected, high values of stomatal conductance and respiratory rates were verified, mainly in plants under full sunshine conditions. Comparing values shown by plants under shading with the plants cultivated under full sunshine, mainly in December 2004, it can be observed that the values of stomatal conductance were null, while plants were still transpiring. During August 2003 and 2004 plants had higher transpiration rates, except the ones under $70 \%$ shading, resulting in lower VDP values.
From August 2004 on, plants showed a strong reduction in stomatal conductance (Gs), mainly in the treatment with $50 \%$ shading, reaching values almost null in December of the same year.

Correlating with Figure 1, it can be verified that the PPDF showed a progressive decrease, mainly in the shading treatments, which can be a regulation factor of stomata closure, resulting in an increase of stomata diffusive resistance and decrease of the respiratory rate. Plants behavior concerning Gs and transpiration is related to low rainfall verified in August and September 2004 (Table 1).
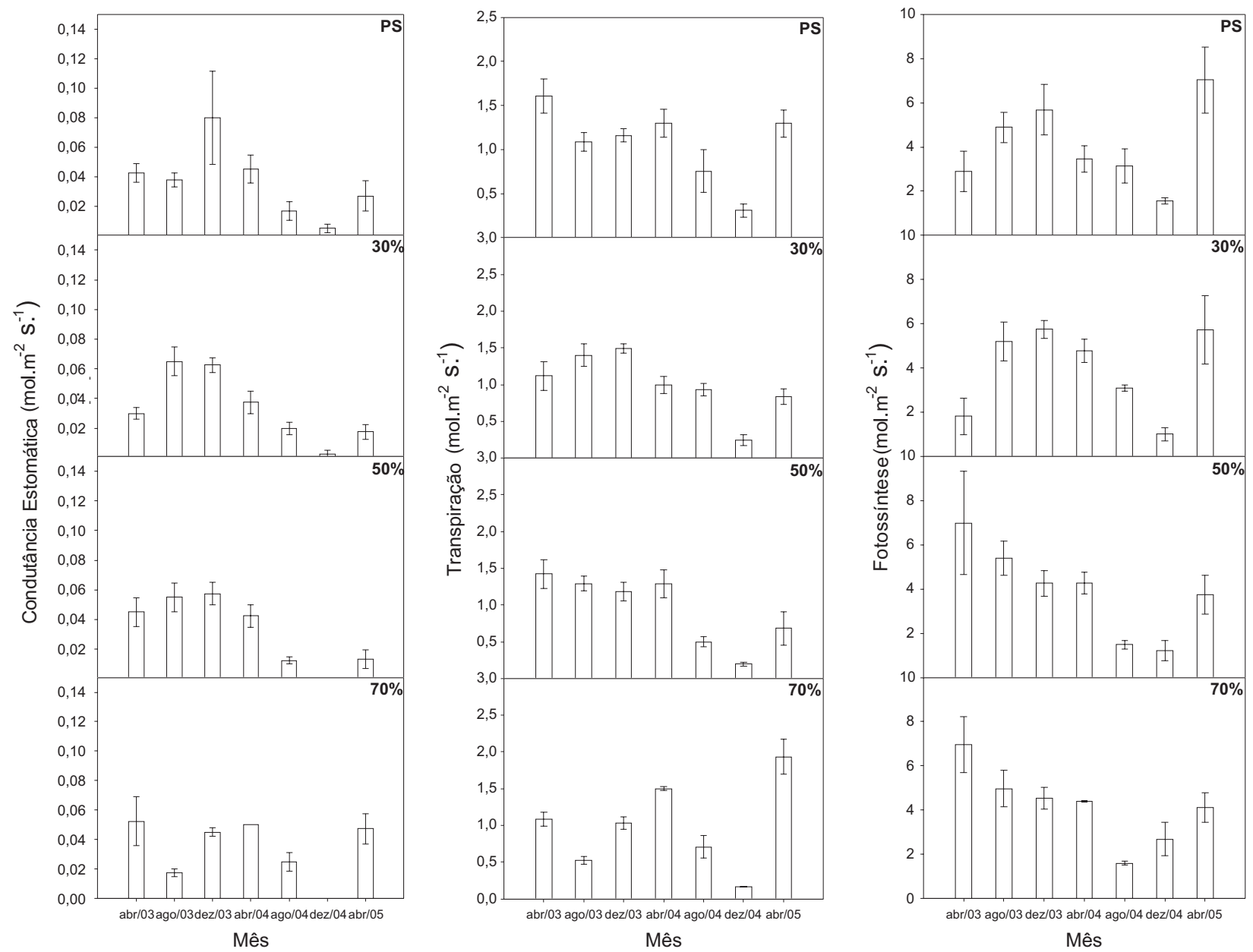

Figure 2 - Average values ( \pm standard error) of stomatal conductance, transpiration and photosynthesis of T. subalbens seedlings under different shading levels during eight evaluation dates.

Figura 2 - Valores médios ( \pm erro padrão) da condutância estomática, transpiração e fotossíntese de plantas jovens de Talisia subalbens (Mart) Radlk, submetidas a diferentes níveis de sombreamento em oito épocas de avaliação.

Revista Árvore, Viçosa-MG, v.35, n.1, p.61-67, 2011 
Table 1 - Net photosynthesis (A), stomatal conductance (Gs), transpiration, chlorophylls $a$, $b$ and total contents (mg.g$\left.{ }^{1} M F\right)$, and chlorophyll a/b ratio in leaves of $T$. subalbens plants under different shading levels.

Table 1 - Fotossíntese líquida (A), condutância estomática (Gs), transpiração, teores de clorofila a, b, total (mg.g-1 MF) e relação clorofila a/b em folhas de T. subalbens submetidas a diferentes níveis de sombreamento.

\begin{tabular}{|c|c|c|c|c|}
\hline Shading Levels & \multicolumn{2}{|c|}{$\begin{array}{l}\text { Net Photosynthesis } \\
\left(\mathrm{mmol} \mathrm{H}_{2} \mathrm{O} \cdot \mathrm{m}^{-2} \cdot \mathrm{s}^{-1}\right)\end{array}$} & $\begin{array}{l}\text { Stomatal conductance } \\
\left(\mu \mathrm{mol} \cdot \mathrm{CO}_{2} \cdot \mathrm{m}^{-2} \cdot \mathrm{s}^{-1}\right)\end{array}$ & $\begin{array}{c}\text { Transpiration } \\
\left(\mathrm{mol} \mathrm{H}_{2} \mathrm{O} \cdot \mathrm{m}^{-2} \cdot \mathrm{s}^{-1}\right)\end{array}$ \\
\hline Full sunshine & \multicolumn{2}{|c|}{$4.092 \mathrm{a}$} & $0.036 \mathrm{a}$ & $1.114 \mathrm{a}$ \\
\hline $30 \%$ & \multicolumn{2}{|c|}{$3.910 \mathrm{a}$} & $0.033 \mathrm{a}$ & $0.972 \mathrm{~b}$ \\
\hline $50 \%$ & \multicolumn{2}{|c|}{$3.907 \mathrm{a}$} & $0.032 \mathrm{a}$ & $0.865 \mathrm{~b}$ \\
\hline \multirow[t]{2}{*}{$70 \%$} & \multicolumn{2}{|c|}{$4.182 \mathrm{a}$} & $0.033 \mathrm{a}$ & $0.871 \mathrm{~b}$ \\
\hline & 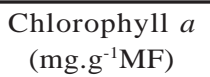 & $\begin{array}{l}\text { Chlorophyll } b \\
\left.\text { (mg.g }{ }^{-1} \mathrm{MF}\right)\end{array}$ & $\begin{array}{l}\text { Total Chlorophyll } \\
\left.\text { (mg.g }{ }^{-1} \mathrm{MF}\right)\end{array}$ & $\begin{array}{l}\text { Chlorophyll } \\
a / b \text { ratio }\end{array}$ \\
\hline Full sunshine & $1.553 \mathrm{~b}$ & $0.585 \mathrm{~b}$ & $2.139 \mathrm{~b}$ & $2.946 \mathrm{a}$ \\
\hline $30 \%$ & $1.375 \mathrm{~b}$ & $0.564 \mathrm{~b}$ & $1.939 \mathrm{~b}$ & $2.434 \mathrm{a}$ \\
\hline $50 \%$ & $1.430 \mathrm{~b}$ & $0.522 \mathrm{~b}$ & $1.953 \mathrm{~b}$ & $2.807 \mathrm{a}$ \\
\hline $70 \%$ & $2.010 \mathrm{a}$ & 0.766 a & $2.776 \mathrm{a}$ & $2.632 \mathrm{a}$ \\
\hline
\end{tabular}

Average values followed by the same letter do not differ statistically from each other at $5 \%$ probability according to the Scott-Knott test.

A progressive decrease in photosynthesis was observed between April and December 2004, except for plants cultivated under $70 \%$ of shading, which showed an increase in photosynthesis during December. This response may be due to a low water availability between the months of April and September. In addition, plants under shading treatment showed low stomatal conductance and transpiration rate during this period (Table 1 ). The evaluation in April showed a higher photosynthesis in plants cultivated under full sunshine and with $30 \%$ shading, favored by an increase in PPDF and in the transpiration rate (Table 1 ).

From April 2004 to April 2005 no difference in net photosynthesis and stomatal conductance was observed between the shading treatments studied. However, plants cultivated under full sunshine, even showing a higher transpiration rate, did not contribute to the carbon assimilation increase. Differences in photosynthesis between the three shading levels studied were not observed (Table 1).

Alvarenga et al. (2003) studying the Croton urucurana Baill species observed higher photosynthetic rates in seedlings cultivated under high irradiance levels. Lima Junior et al. (2005) found similar results while studying Cupania vernalis Camb. under different irradiance levels, observing higher values of photosynthesis and stomatal conductance in plants under full sunshine and with 30\% shading, although transpiration values did not differ.
T. subalbens seedlings leaf photosynthetic pigments showed higher contents of chlorophylls $a, b$ and total, under $70 \%$ of shading in comparison with the other treatments, which did not differ between themselves. A difference in the ration chlorophyll a/b between the treatments was not observed (Table 1 ).

The increased chlorophyll content related to lower radiation levels is being widely reported in literature, mainly in studies with forestry species such as Croton urucurana (Alvarenga et al., 2003), Bombacopsis glabra (Pasq.) (Scalon et al., 2003), Cryptocarya aschersoniana (Almeida et al., 2004), Cupania vernalis (Lima Junior et al., 2005), Maclura tinctoria (L.) D. Don ex Steud., Senna macranthera (Collad.) Irwin et Barn., Hymenaea courbaril L. var. stilbocarpa (Hayne) Lee et Lang. and Acacia mangium Willd. (Almeida et al., 2005b).

The increase in the chlorophyll $b$ relative proportion is an important characteristic of shaded environments because it catches the photons energy in longer wavelengths, therefore, with less energy and transfers it to chlorophyll $a$ which acts effectively in the photosynthesis photochemical reactions. This mechanism allows some plants to adapt to conditions of less luminous intensity due to a higher efficiency in the absorption of the luminous energy of less intensity, as well as an amplification of the photosynthetic active spectrum (Whatey \& Whatey, 1982).

The chlorophyll $a / b$ ratio is closely related to the plant's capacity to maximize the light uptake under conditions of higher shading. The increase of the relative proportion of chlorophyll $b$ compared to chlorophyll $a$ is related to the photosystem II efficiency (Nakazono et al., 2001).

Revista Árvore, Viçosa-MG, v.35, n.1, p.61-67, 2011 
Table 2 - Shoot, root, and total plant dry biomass, root/shoot ratio, average values of height, basal diameter, and leaf area of $T$. subalbens seedlings under different shading levels.

Table 2 - Biomassa seca de parte aérea, raiz, total, relação raiz/parte aérea, valores médios de altura, diâmetro do caule e de área foliar de plantas jovens T. subalbens, submetidas a diferentes níveis de sombreamento.

\begin{tabular}{|c|c|c|c|c|c|c|c|}
\hline \multirow[t]{2}{*}{ Shading levels } & \multicolumn{3}{|c|}{ Dry Biomass (g) } & \multirow[t]{2}{*}{ Root/Shootratio } & \multirow[t]{2}{*}{ Height(cm) } & \multirow{2}{*}{$\begin{array}{c}\text { Basal Diameter } \\
(\mathrm{mm})\end{array}$} & \multirow{2}{*}{$\begin{array}{c}\text { Leaf } \\
\text { area }\left(\mathrm{dm}^{2}\right)\end{array}$} \\
\hline & Shoot & Root & Total plant & & & & \\
\hline Full sunshine & $4.01 \mathrm{a}$ & $22.35 \mathrm{a}$ & $26.36 \mathrm{a}$ & 5.89 a & $12.12 \mathrm{a}$ & $5.88 \mathrm{a}$ & $6.00 \mathrm{a}$ \\
\hline $30 \%$ & $2.26 \mathrm{~b}$ & $14.69 \mathrm{~b}$ & $16.95 \mathrm{~b}$ & 6.83 a & 10.76 а & $5.40 \mathrm{a}$ & $4.60 \mathrm{~b}$ \\
\hline $50 \%$ & $2.13 \mathrm{~b}$ & $14.74 \mathrm{~b}$ & $16.90 \mathrm{~b}$ & 6.81 a & $7.92 \mathrm{~b}$ & $3.92 \mathrm{~b}$ & $3.80 \mathrm{c}$ \\
\hline $70 \%$ & $2.04 \mathrm{~b}$ & $12.61 \mathrm{~b}$ & $14.66 \mathrm{~b}$ & $6.86 \mathrm{a}$ & $8.12 \mathrm{~b}$ & $3.88 \mathrm{~b}$ & $3.80 \mathrm{c}$ \\
\hline
\end{tabular}

Average values followed by the same letter do not differ statistically from each other at 5\% probability according to the Scott-Knott test.

Related to initial growth and biomass allocation, it was observed that plants cultivated under full sunshine showed a higher accumulation of total, shoot, and root dry biomass (Table 2). No significant difference was observed in the root/shoot ratio between the treatments studied. It was also verified that seedlings cultivated under full sunshine and with $30 \%$ of shading showed higher values of total height and basal diameter. Higher values of leaf area were observed in plants under full sunshine, followed by treatments with $30 \%$ shading (Table 2 ).

Plants cultivated under $50 \%$ and $70 \%$ of shading showed lower values of basal diameter and leaf area when compared to plants grown under higher irradiance levels. Based on the characteristics evaluated, the necessity of relatively high irradiance levels for the initial development of 'cascudo' seedlings is evident, being this species classified as heliophytic.

Little plants have their shoot development favored by conditions of full sunshine, such as Cryptocarya aschersoniana Mez. (Almeida et al., 2004), Jacaranda puberula Cham (Almeida et al., 2005b) and Bombacopsis glabra (Scalon et al., 2003).

Analyzing T. subalbens shoot and root system biomass distribution it can be verified that in all levels of shading evaluated, from $85 \%$ to $87 \%$ of the photoassimilates have been allocated to the roots and from $13 \%$ to $15 \%$ to the shoot (data not presented).

Many species when exposed to full sunshine conditions have their shoot growth negatively influenced, however this condition can also favor the biomass allocation to root systems. This relation has a fundamental importance to the recovery of disturbed and degraded areas, once the success of reforestry programs depends on high irradiance conditions and eventual situations of stress, mainly water stress (Hoffmann \& Franco, 2003).

Revista Árvore, Viçosa-MG, v.35, n.1, p.61-67, 2011
Alvarenga et al. (2003) observed that Croton urucurana Baill seedlings kept under full sunshine conditions showed lower leaf area and higher biomass accumulation in the root system under full sunshine and with 30\% of shading. While Lima Júnior et al. (2005), studying Cupania vernalis Cam., verified that plants cultivated under full sunshine accumulated less biomass in shoot, showing a lower high basal diameter and leaf area and a higher root/shoot ratio.

To the species $T$. subalbens, in all radiation treatments studied, biomass distribution was higher for tuberous roots (data not presented). Several authors still report that sun plants allocate higher biomass percentages to root system, and also invest in the formation of tuberous roots. Ramos et al. (2004), studying the species Amburana cearensis (Allemao) A.C. Smith, observed a higher total biomass under full sunshine, followed by $50 \%$ and $70 \%$ of shading. The same authors verified that the height and basal diameter did not differ and that under full sunshine plants showed a higher biomass allocation rate to the root system. Almeida et al. (2005b) verified that under full sunshine the pioneer species Acacia mangium allocated more biomass to the leaves while the climax species Maclura tinctoria accumulated more biomass in the roots.

\section{CONCLUSIONS}

In plants of Talisia subalbens shading affects growth, gas exchange and chlorophyll content. The best condition for the seedlings growth is under full sunshine.

\section{REFERENCES}

ALMEIDA, L. P. et al. Crescimento inicial de Cryptocaya aschersoniana Mez. submetidas a diferentes níveis de radiação solar. Ciência Rural, v.34, n.1, p.83-88, 2004.

\footnotetext{
Revista Arvore, Viçosa-MG, v.35, n.1, p.61-67, 2011
} 
ALMEIDA, L. S. et al. Crescimento de mudas de Jacaranda puberula Cham. em viveiro submetidas a diferentes níveis de luminosidade. Ciência Florestal, v.15, n.3, p.323-329, 2005a.

ALMEIDA, S. M. Z. et al. Alterações morfológicas e alocação de biomassa em plantas jovens de espécies florestais sob diferentes condições de sombreamento. Ciência Rural, v.35, n.1, p.62-68, 2005b.

ALVARENGA, A. A. et al. Effects of different light levels on the initial growth and photosynthesis of Croton urucurana Baill. in southeastern Brazil. Revista Árvore, v.27, n.1, p.53-57, 2003.

ARNON, D. I. Cooper enzymes in isolated chloroplasts. Polyphenoloxidase in Beta vulgaris. Plant Physiology, v.24, n.1, p.1-15, 1949.

FERREIRA, D. F. Análises estatísticas por meio do Sisvar para Windows versão 4.0. In: REUNIÃO ANUAL DA REGIÃO BRASILEIRA DA SOCIEDADE INTERNACIONAL DE BIOMETRIA, 45., 2000, São Carlos. Anais... São Carlos: UFSCar, 2000. p.255-258.

GAJEGO, E. B. et al. Crescimento de plantas jovens de Maclura tinctoria e Hymenaea courbaril em diferentes condições de sombreamento. In: CONGRESSO NACIONAL DE FISIOLOGIA, 8., 2001, Ilhéus. Trabalhos Apresentados... Ilhéus: 2001. CD ROM

GUARIN NETO, G. Talisia subalbens (MART.) RADLK. (SAPINDACEAE): espécie endêmica do Cerrado de Mato Grosso. In: CONGRESSOS NACIONAIS DE BOTÂNICA, 53., 2002, Recife. Anais... Recife: Universidades Federais de Pernambuco, 2002. p.305.
HOFFMANN, W. A.; FRANCO, A. C. Comparative growth analysis of tropical forest and savanna woody plants using phylogenetically-independent contrasts. Journal of Ecology, v.91, n.3, p.475-484, 2003.

JOHNSON, C. M. et al. Comparative chlorine requirements of different plant species. Plant and Soil, v.8, p.337-353, 1957.

LIMA JUNIOR, E. C. et al. Aspectos fisioanatômicos de plantas jovens de Cupania vernalis Camb. submetidas a diferentes níveis de sombreamento. Revista Árvore, v.30, n.1, p.33-41, 2006.

LIMA JUNIOR, E. C. et al. Trocas gasosas, características das folhas e crescimento de plantas jovens de Cupania vernalis Camb. submetidas a diferentes níveis de sombreamento.

Ciência Rural, v.35, n.5, p.1092-1097, 2005.

NAKAZONO, E. M. et al. Crescimento inicial de Euterpe edulis Mart. em diferentes regimes de luz. Revista Brasileira de Botânica, v.24, n.2, p.173-179, 2001.

RAMOS, K. M. O. et al. Desenvolvimento inicial e repartição de biomassa de Amburana cearensis (Allemao) A. C. Smith, em diferentes condições de sombreamento. Acta Botanica Brasilica, v.18, n.2, p.351-358, 2004.

SCALON, S. P. Q. et al. Crescimento inicial de mudas de Bombacopsis glabra (Pasq.) A. Robyns sob condição de sombreamento. Revista Árvore, v.27, n.6, p.753-758, 2003.

Whatley, F. H.; Whatley, F. R. A luz e a vida das plantas: temas de biologia. São Paulo: EDUSP, 1982. v.30. 101p. 
